\title{
Initial and Long-Term Treatment of Pulmonary Embolism: Current Approach and Future Perspectives
}

\author{
Marco P. Donadini ${ }^{1}$ Walter Ageno ${ }^{1,2}$ \\ ${ }^{1}$ Short Medical Stay Unit and Thrombosis Center, Department of \\ Clinical Medicine, Ospedale di Circolo e Fondazione Macchi, Azienda \\ Socio Sanitaria Territoriale dei Sette Laghi, Varese, Italy \\ 2 Research Center on Thromboembolic Diseases and Antithrombotic \\ Treatment, Department of Medicine and Surgery, University of \\ Insubria, Varese, Italy
}

\begin{abstract}
Address for correspondence Marco Paolo Donadini, MD, PhD, Short Medical Stay Unit and Thrombosis Center, Department of Clinical Medicine, Ospedale di Circolo e Fondazione Macchi, Azienda Socio Sanitaria Territoriale dei Settelaghi, Viale Borri 57, 2110 Varese, Italy (e-mail: mp.donadini@gmail.com).
\end{abstract}

Hämostaseologie 2018;38:75-86.

\section{Abstract}

Keywords

- pulmonary embolism

- risk stratification

- direct oral anticoagulants

- extended therapy

\section{Zusammenfassung}

\section{Schlüsselwörter}

- Lungenembolie

- Risikostratifizierung

- Direkte orale Antikoagulanzien

- Dauertherapie
Pulmonary embolism is associated with variable risk of early mortality, ranging from less than $1 \%$ to more than $15 \%$. Risk stratification, based on clinical variables and signs of right ventricular dysfunction, is crucial to decide the best management and treatment strategy. Home therapy may be an option for low-risk patients, whereas patients at intermediate risk need to be hospitalized and some of them, at intermediate high risk, may require more intensive monitoring to early detect signs of haemodynamic decompensation. The initial treatment is based on anticoagulants with rapid onset of action, either parenteral (heparin/ fondaparinux) or oral (direct oral anticoagulants, DOACs). Thereafter, DOACs (or, if contraindicated, vitamin $\mathrm{K}$ antagonists) needs to be continued for at least 3 months. Beyond this period, an individual re-evaluation of the risk-to-benefit ratio of anticoagulation should be performed, based on several factors, including the type of index event, age, sex, D-dimer and residual venous obstruction. Possibly safer strategies can be offered to higher risk patients requiring extended duration of treatment, including the DOACs apixaban and rivaroxaban at reduced dose.

Bei Lungenembolien besteht ein variables, zwischen unter $1 \%$ und mehr als $15 \%$ liegendes Risiko der Frühmortalität. Für die Entscheidung über das beste Management und die Behandlungsstrategie ist eine Risikostratifizierung auf Grundlage der klinischen Parameter und der rechtsventrikulären Dysfunktion unabdingbar. Für Patienten mit niedrigem Risiko kann eine Heimtherapie in Frage kommen, während Patienten mit mittlerem Risiko stationär behandelt werden müssen; bei einem höheren bis hohen Risiko ist eventuell eine intensivere Überwachung nötig, um Anzeichen für eine hämodynamische Dekompensation frühzeitig aufzudecken. Die Anfangsbehandlung besteht aus Antikoagulantien mit raschem Wirkungseintritt, entweder parenteral (Heparin/Fondaparinux) oder oral (direkte orale Antikoagulantien, DOAKs). Anschließend sind für mindestens 3 Monate DOAKs (oder, wenn kontraindiziert, Vitamin K- Antagonisten) zu verabreichen. Danach sollte, auf der Basis verschiedener Faktoren, wie Art des Index-Ereignisses, Alter, Geschlecht, D-Dimer und venöse thrombotische Residuen, eine individuelle Neubewertung des Nutzen-/Risikoverhältnisses der Antikoagulation erfolgen. Hochrisikopatienten, die eine längere Therapiedauer benötigen, kann man potenziell sicherere Alternativen anbieten, z. B. die DOAKs Apixaban und Rivaroxaban in geringerer Dosis. received

July 14, 2017

accepted after revision

December 11, 2017
Copyright @ 2018 Schattauer
DOI https://doi.org/

10.1055/s-0038-1641605. ISSN 0720-9355. 


\section{Introduction}

Anticoagulant therapy is the mainstay of treatment for pulmonary embolism (PE). In recent years, several novel therapeutic options have become available as alternatives to the standard of treatment, both for the acute and long-term treatment. Meanwhile, the importance of prognostic stratification of PE in the acute phase has been widely recognized and is now recommended in clinical practice. Therefore, therapeutic strategies can now be tailored on individual patient characteristics. This also applies to the secondary prevention of venous thromboembolism (VTE), for which possibly safer strategies can be offered to higher risk patients requiring extended duration of treatment. On-going clinical trials are now assessing new agents that can further contribute to improve the management of PE patients.

\section{Initial Treatment}

\section{Prognostic Stratification}

PE may display many different clinical characteristics at presentation, including chest pain, dyspnoea, haemoptysis, cough, tachycardia, fever and syncope. Less commonly, the clinical presentation can be either very mild or even silent (unsuspected PE) or very severe, with haemodynamic collapse. This latter clinical scenario is associated with the highest mortality rates (early mortality $>15 \%$ ) and warrants immediate reperfusion therapies, including pharmacological and/or mechanical thrombolysis. In all other cases (i.e., PE without shock or persistent hypotension), it is crucial to stratify the short-term risk of adverse outcomes, to choose the optimal management strategy. Indeed, not only the clinical presentation may inform physicians about the risk of early mortality, but several additional variables should be taken into consideration, including age and sex, personal history of reduced cardiovascular reserve, active cancer, right ventricular dysfunction (RVD) or injury and site and extension of thrombosis.

As suggested by current clinical guidelines, ${ }^{1,2}$ when PE patients are haemodynamically stable, a primary distinction should be done to identify those patients at very low risk of adverse outcome (30 days mortality $<1 \%$ ).

For this purpose, the European Society of Cardiology (ESC) guidelines suggest the use of the Pulmonary Embolism Severity Index (PESI) or its simplified version (SPESI), ${ }^{3,4}$ a clinical prediction model (CPM) that includes 11 (or 6 in the simplified version) easily available variables. Even if PESI has yet to be supported by the results of an impact analysis, it represents the most widely validated CPM in this setting. ${ }^{5,6}$ As demonstrated by several studies, PESI has a high negative predictive value, being able to adequately identify PE patients at low risk of short-term adverse outcome. ${ }^{5}$

Other variables have been shown to be associated with PE prognosis, including right-to-left ventricle diameter ratio at computed tomography (CT) scan, RVD at echocardiography, brain natriuretic peptide (BNP) and troponin levels. These parameters have shown high negative predictive values, although none has the same performance of PESI to discrim- inate patients at low risk. ${ }^{1}$ On the other hand, all these variables are associated with the risk of early mortality with odds ratios that vary between $\sim 2$ and 6 . $^{2}$ Therefore, these markers have been proposed to identify haemodynamically stable patients at intermediate risk of early mortality.

\section{Therapeutic Approach}

The treatment of PE traditionally consists of three subsequent phases, initial (0-7 days), long-term (from 7 days to 3 months) and extended (from 3 months to indefinite).

The initial treatment requires anticoagulant drugs with a rapid onset of action, such as the parenteral heparins/fondaparinux or the direct oral anticoagulants (DOACs). Low-molecular weight heparin (LMWH), unfractionated heparin (UFH) or fondaparinux are administered for at least 5 days, either in association with the vitamin $\mathrm{K}$ antagonists (VKAs) or preceding the administration of the DOACs dabigatran or edoxaban. In contrast, the DOACs apixaban and rivaroxaban can be administered without lead-in parenteral treatment from the beginning, with a loading dose given for 7 or 21 days, respectively ( - Table 1 ).

The choice of the treatment strategy depends on patient characteristics and on the clinical setting. DOACs were shown to be non-inferior to warfarin in terms of efficacy ${ }^{7-12}$ and to significantly reduce the risk of major bleeding and intracranial bleeding, this latter by $\sim 50 \%{ }^{13}$ The efficacy and safety of the DOACs in patients with VTE has been confirmed by the results of post-marketing studies. ${ }^{14-17}$ Thus, evidence-based guidelines now suggest DOACs as the first treatment option for patients with PE. ${ }^{18}$

VKAs remain a valid option in particular when contraindications to DOACs exist, such as severe renal or liver failure or concomitant use of interfering drugs such as strong inducers/inhibitors of CYP3A4 and competitors/inducers of P-glycoprotein (e.g., human immunodeficiency virus [HIV] protease inhibitors, azole antimycotics, carbamazepine, phenytoin, phenobarbital). ${ }^{19}$

Patients with cancer-associated PE carry the highest risk of recurrence ( $20-25 \%$ per year $)^{20,21}$ and benefit from $\mathrm{LMWH}$, that is recommended for both the acute and the long-term phase of treatment for up to 3 to 6 months. ${ }^{18,22-24}$ LMWH was shown to be superior to warfarin at reducing the risk of VTE recurrence (hazard ratio [HR], 0.47; 95\% confidence interval $[\mathrm{CI}], 0.32-0.71)$ with a similar risk of bleeding events $^{25}$ ( - Table 1 ).

Cancer patients in phase III trials of DOACs are underrepresented. Although sub-group analyses suggest DOACs are effective in reducing the risk of recurrent VTE as compared with VKAs, ${ }^{26}$ no head-to-head comparison with LMWH is currently available. Randomized controlled trials directly comparing DOACs with LMWH in the acute treatment of VTE have recently completed enrolment (Hokusai-Cancer trial) $)^{27}$ or are on-going (Caravaggio trial, NCT03045406).

\section{Setting of Care}

Patients identified to be at low risk of short-term adverse outcomes represent at least $40 \%$ of PE patients and may 
Table 1 Therapeutic options for initial and early maintenance therapy

\begin{tabular}{|c|c|c|c|c|c|c|}
\hline & Apixaban & Edoxaban & Rivaroxaban & Dabigatran & VKA & $\begin{array}{l}\text { LMWH } \\
\text { (cancer } \\
\text { patients) }\end{array}$ \\
\hline $\begin{array}{l}\text { Initial } \\
\text { treatment }\end{array}$ & $\begin{array}{l}10 \mathrm{mg} \text { bid } \\
\text { for } 7 \mathrm{~d}\end{array}$ & $\begin{array}{l}\text { Parenteral } \\
\text { anticoagulation } \\
\text { for at least } 5 \mathrm{~d} \text {, } \\
\text { then } 60 \mathrm{mg} \mathrm{od}^{\mathrm{a}}\end{array}$ & $\begin{array}{l}15 \mathrm{mg} \text { bid } \\
\text { for } 21 \mathrm{~d}\end{array}$ & $\begin{array}{l}\text { Parenteral } \\
\text { anticoagulation } \\
\text { for at least } 5 \mathrm{~d} \text {, } \\
\text { then } 150 \mathrm{mg}^{\mathrm{bid}}{ }^{\mathrm{b}}\end{array}$ & $\begin{array}{l}\text { Parenteral anticoagulation } \\
\text { for at least } 5 \mathrm{~d} \text { associated } \\
\text { with VKA AND until } \\
\text { INR } \geq 2 \text {, then VKA } \\
\text { only (INR range, } 2-3 \text { ) }\end{array}$ & $\begin{array}{l}\text { Full dose } \\
\text { for } 1 \text { mo }\end{array}$ \\
\hline $\begin{array}{l}\text { Early } \\
\text { maintenance } \\
\text { therapy }\end{array}$ & $5 \mathrm{mg}$ bid & $60 \mathrm{mg} \mathrm{od}^{\mathrm{a}}$ & $20 \mathrm{mg}$ od & $150 \mathrm{mg} \mathrm{bid}^{\mathrm{b}}$ & INR, 2-3 & $\begin{array}{l}50-75 \% \text { of } \\
\text { full dose } \\
\text { after } 1 \text { st mo }\end{array}$ \\
\hline
\end{tabular}

Abbreviations: INR, international normalized ratio; LMWH, low-molecular weight heparin; VKA, vitamin K antagonists.

aDoses should be reduced, as tested in the Hokusai trial and according the Summary of Product Characteristics, to 30 mg od for patients with one or more of the following factors: creatinine clearance $15-50 \mathrm{~mL} / \mathrm{min}$; body weight $\leq 60 \mathrm{~kg}$; concomitant treatment with potent P-gp inhibitors (ciclosporin, dronedarone, erythromycin, ketoconazole).

bDoses should be reduced, according the Summary of Product Characteristics (not directly tested in the RE-COVERY I and II trials), to 110 mg bid for patients aged $\geq 80$ years and/or receiving concomitant verapamil and should be considered for the following groups, based on an individual assessment of the thromboembolic risk and the risk of bleeding:

- Patients between 75 and 80 years.

- Patients with moderate renal impairment.

- Patients with gastritis, oesophagitis or gastro-oesophageal reflux.

- Other patients at increased risk of bleeding.

benefit from a short hospital stay (48 hours) or home treatment. ${ }^{5,28}$ This option is currently suggested for patients who have also adequate home circumstances. ${ }^{1,18}$

Several approaches have been proposed to identify and manage this group of PE patients. In a randomized controlled trial comparing discharge after PE diagnosis at the emergency department with hospitalization in low-risk patients defined by PESI class I-II or simplified PESI 0, no increase in adverse events was documented. ${ }^{28}$ In two prospective cohort management studies, patients suitable for outpatient treatment defined by the Hestia criteria (a list of exclusion criteria for home treatment), were safely managed with very low rates of adverse events. ${ }^{29,30}$

This approach may be appealing in several countries, since the mean length of hospital stay (LOS) for PE remains high both in Europe and in the United States. ${ }^{31-33}$ It should be also mentioned that the use of the DOACs has already resulted in a reduction of LOS in patients with venous thrombosis. ${ }^{14}$ In addition, a trend towards a reduction of LOS was already observed in recent years, even before the availability of DOACs, probably due to the improved prognostic stratification. ${ }^{32,33}$

For patients with PESI risk class III-IV-V or simplified PESI $\geq 1$, the risk of early mortality is not negligible and hospitalization is recommended. Because this group defined at intermediate risk is heterogeneous, with mortality rates ranging from 2 to 10 to $15 \%$, a further stratification into intermediate-low and intermediate-high risk was proposed. ${ }^{2}$ This latter group benefits from a more intensive monitoring to early detect signs of haemodynamic decompensation. The simultaneous presence of imaging signs of RVD and the positivity of cardiac laboratory biomarkers, as suggested by the ESC guidelines to identify intermediate-high risk patients, was adopted in the PEITHO trial, a randomized controlled trial comparing systemic fibrinolysis with placebo on top of anticoagulant therapy. ${ }^{34}$ This approach was effective to identify patients who could benefit from treatment with tenecteplase, with a significant reduction in the combined primary outcome of mortality and haemodynamic decompensation (but no significant reduction in mortality alone), although this benefit was offset by a significant increase in major bleeding rates.

The DOACs have not been tested in specifically designed trials on PE patients at intermediate-high risk of mortality. A sub-group analysis of the HOKUSAI VTE trial found a statistically significant reduction with $\mathrm{LMWH} / \mathrm{edoxaban}$, as compared with LMWH/warfarin in VTE recurrence (HR, 0.52 ; 95\% CI, 0.28-0.98) in PE patients with RVD defined by increased N-terminal pro-BNP levels. ${ }^{35}$ In the EINSTEN-PE trial, patients with anatomically extensive PE treated with rivaroxaban showed a similar incidence of VTE recurrence as compared with patients treated with $\mathrm{LMWH} /$ warfarin $(2.5 \%$ vs. $2.2 \%) .{ }^{10}$ However, the question on whether lead-in parenteral treatment in PE patients at intermediate-high risk is warranted remains open.

Finally, in case of shock or sustained hypotension at presentation, reperfusion therapy should be performed by using systemic fibrinolysis, unless contraindicated. Alternative strategies in case of high bleeding risk or fibrinolysis failure include the use of endovascular or surgical thromboembolectomy. This issue is specifically discussed in another article included in this issue by Kucher et al.

\section{Long-Term and Extended Treatment}

\section{Who Should Continue on Anticoagulation}

After the initial acute phase, patients should continue on anticoagulant therapy for at least 3 months. ${ }^{18}$ Beyond this period, there is adequate evidence to suggest that continuing anticoagulation for a definite time only postpones the risk of 
VTE recurrence, without substantially reducing it (so-called 'catch-up' phenomenon). ${ }^{36,37}$ It should be noted, however, that clinicians tend to prolong the duration of treatment up to 6 to 12 months, in case of both provoked and unprovoked event. $^{38}$

When deciding the optimal duration of anticoagulation, the individual risk of recurrent VTE must be balanced against the risk of bleeding, taking into consideration several clinical variables and also patients values and preferences. The major determinant of the recurrence risk is represented by the presence and type of provoking factors identified at the time of the index event. In the presence of major transient risk factors, such as major surgery, pregnancy/puerperium, immobilization due to trauma or related to an acute medical illness, the risk of recurrence is low $(<5 \% / \text { year })^{39-41}$ and continuation of anticoagulation beyond 3 months is not warranted. On the other end of the spectrum, permanent provoking factors such as active cancer or chronic inflammatory diseases are associated with a high risk of recurrence and, thus, indefinite anticoagulation is warranted. ${ }^{41}$

However, in up to $50 \%$ of patients with PE a major provoking factor cannot be identified. In these patients, recurrence rates have been reported to be as high as $50 \%$ after 8 to 10 years, ${ }^{42}$ and indefinite duration of anticoagulation is suggested by evidence-based guidelines when bleeding risk is sufficiently low. However, this group of PE patients is quite heterogeneous and this approach may not be necessary for all patients. Some baseline characteristics have been consistently associated with a higher risk of recurrence, with a mild to moderate strength of association: male sex, age $>65$ years and obesity. Moreover, thrombus location was also found to be associated with the risk of recurrent VTE, with an increasing risk going from distal deep vein thrombosis (DVT) to proximal DVT to PE. Also, it has been shown that patients presenting with PE are more likely to recur with PE. Finally, some variables measured at the end of anticoagulant therapy may also assist clinicians to determine the optimal duration of treatment, including the presence of residual venous occlusion (RVO) or residual perfusion defects, post-thrombotic syndrome (PTS) or elevated D-dimer.

$\mathrm{RVO}$, that is measured by means of compression ultrasound of the veins involved in DVT, has been shown to be independently associated with recurrent VTE, with variable strength across several studies. ${ }^{43-47}$ An individual patient data meta-analysis found that RVO is meaningful when measured at 3 months after the index event, with a HR of 2.17 (95\% CI, 1.11-4.25). ${ }^{48}$ Recently, also residual pulmonary obstruction was shown to be independently associated with recurrent VTE in two cohort studies conducted in Italy and in France, with HR of 2.26 (95\% CI 1,.23-4.16) and 1.94 (95\% CI, $1.11-3.39)$, respectively. ${ }^{49,50}$

In several studies enrolling patients with unprovoked or 'weakly-provoked' VTE who completed at least 3 months of anticoagulation, D-dimer was measured just before withholding anticoagulation or within the subsequent month to evaluate its ability to predict recurrent VTE. The results of these studies invariably show that D-dimer is significantly associated with the risk of recurrent VTE. ${ }^{51,52}$ Subsequently, D-dimer was used in combination with RVO in a management study that demonstrated that anticoagulation can be safely withdrawn in $\sim 40 \%$ of patients with unprovoked VTE who have negative D-dimer associated with the absence of RVO (in case of DVT) or normal pulmonary artery pressure (in case of PE). ${ }^{53}$ Moreover, D-dimer is included in all the three available CPMs on the risk of recurrent VTE.

Even if the abovementioned variables are independent predictors of recurrent VTE, their association is not strong enough to rely on their value when deciding to prolong or discontinue anticoagulation. To improve the prediction of VTE recurrence, CPMs have been proposed, derived and validated to select a group of patients with unprovoked VTE who can safely discontinue anticoagulant treatment at the end of the initially planned period (at least 3 months) (-Table 2). ${ }^{54}$ The Canadian 'men continue and HERDOO2' rule was first derived and internally validated in 2008 , showing that men are at high risk of recurrence, as well as women with at least two characteristics among 'HER' (hyperpigmentation, oedema, redness in either leg), positive ' $D$ '-dimer ( $\geq 250 \mu \mathrm{g} / \mathrm{L}$, measured during anticoagulant treatment), older age ( $\geq 65$ years) and obesity (body mass index $\geq 30$ ). ${ }^{55}$ This rule was recently validated in a multinational prospective cohort management study, that showed that $\sim 50 \%$ of women were classified as low risk and therefore discontinued anticoagulant treatment, with

Table 2 Clinical prediction models for recurrent VTE after first unprovoked VTE

\begin{tabular}{|l|l|l|l|l|l|}
\hline \multicolumn{2}{|l|}{ DASH $^{57}$} & \multicolumn{2}{l|}{$\begin{array}{l}\text { MEN CONTINUE and } \\
\text { HER-DOO2 }\end{array}$} & \multicolumn{2}{l|}{ VIENNA model $^{59}$} \\
\hline $\mathrm{D}_{2}$ & $\begin{array}{l}\text { D-dimer } \\
\text { (qualitative or } \geq 500 \mathrm{ng} / \mathrm{mL} \\
\text { at 3-5 wk) }\end{array}$ & Men & Male sex & Sex & Male/Female \\
\hline $\mathrm{A}_{1}$ & Age $\leq 50 \mathrm{y}$ & HER 1 & $\begin{array}{l}\text { Hyperpigmentation, oedema } \\
\text { or redness in either leg }\end{array}$ & Extension & $\begin{array}{l}\text { Pulmonary embolism, } \\
\text { proximal DVT, } \\
\text { distal DVT }\end{array}$ \\
\hline $\mathrm{S}_{1}$ & Male sex & $\mathrm{D}_{1}$ & $\begin{array}{l}\text { D-dimer } \geq 250 \mathrm{ng} / \mathrm{mL} \\
\text { on warfarin }\end{array}$ & D-dimer & Quantitative scale ( $\mu \mathrm{gg} / \mathrm{L})$ \\
\hline $\mathrm{H}_{-2}$ & Hormone use in women & $0_{1}$ & Body mass index $\geq 30$ & & \\
\hline & & $0_{1}$ & Age $\geq 65 \mathrm{y}$ & & \\
\hline
\end{tabular}

Abbreviations: DVT, deep vein thrombosis; VTE, venous thromboembolism. 
an incidence of recurrent VTE of 3.0\% per patient year $(95 \% \mathrm{CI}$, $1.8-4.8 \%)^{56}$

The DASH score was originally derived and internally validated in 2012 within an individual patient data metaanalysis and is based on positive post-anticoagulation Ddimer ( 2 points), age $\leq 50$ years ( 1 point), male sex ( 1 point) and hormone use at time of initial VTE in women only $(-2$ points). The annual incidence of recurrent VTE was 3.1\% (95\% CI, 2.4-3.9) in patients with a DASH score of $\leq 1$ and $9.3 \%$ (95\% CI, 8.1-10.8) in patients with a DASH score of $>1 .^{57}$ This model has been recently externally validated in a prospective cohort study. ${ }^{58}$

Finally, the Vienna model was published in 2010 and includes sex, site of index event and D-dimer. A nomogram based on the model was designed to easily calculate patients' cumulative recurrence rate at 12 and 60 months after cessation of therapy. ${ }^{59}$ More recently, the original model was updated, by recalculating the risk of recurrence using new measurements of D-dimer levels at 3, 9 and 15 months after cessation of therapy. ${ }^{60}$ The Vienna prediction model is currently being tested in a randomized trial, in comparison to usual care, to decide on treatment duration (the VISTA study). ${ }^{61}$

All these CPMs can support clinicians when deciding on the duration of anticoagulant treatment. Indeed, they may represent a useful tool to identify some sub-groups of patients who are at low risk of recurrence. However, it should be noted that none of these CPM has been extensively validated and only the HERDOO2 model has been tested in a single management study. ${ }^{56}$ Moreover, for patients not identified at low risk of recurrence, the decision should still be taken on an individual basis, taking into account also the bleeding risk and patients' values and preferences. Therefore, these CPMs can support clinicians when deciding on anticoagulant treatment continuation after a first episode of unprovoked VTE, but, at the moment, they should not be considered as single tools to rely on.
In addition to the abovementioned CPMs, several scores have also been proposed to stratify the risk of bleeding in patients receiving anticoagulant treatment for VTE. These scores may be of some help when balancing the recurrence and bleeding risks, even if the predictive value of most of them needs to be better confirmed. ${ }^{62}$ Ideally, some recently validated bleeding scores, which showed good predictive performances, ${ }^{63,64}$ should be tested in management studies before being implemented in clinical practice.

\section{Therapeutic Options for Extended Treatment}

Several treatment options have been assessed in the extended treatment phase of VTE. These include oral anticoagulants (DOACs or VKA), acetylsalicylic acid (ASA) and sulodexide.

Oral anticoagulants represent the first choice in terms of efficacy, because they are associated with a $90 \%$ reduction of the risk of recurrent VTE as compared with placebo.

The use VKAs is associated with a 1 to $2 \%$ yearly risk of major bleeding. ${ }^{65}$ To improve their safety, lower intensity strategies were tested (international normalized ratio [INR] range, $1.5-2$ ), but failed to show a clinical benefit. ${ }^{66,67}$

The DOACs have been extensively assessed in the extended treatment of VTE, but only in one study dabigatran was compared with warfarin, showing similar efficacy and safety (although a non-statistically significant $50 \%$ reduction of major bleeding events was observed with the use of dabigatran).$^{68}$ In all other studies, the DOACs were compared with placebo or ASA ( - Table 3 ).

In the RE-SONATE trial, dabigatran was associated with a significant reduction of the risk of VTE recurrence, as compared with placebo (HR, 0.08, 95\% CI, 0.02-0.25). ${ }^{68}$

The AMPLIFY-Extension trial showed that apixaban given at reduced-dose (2.5 twice daily) significantly lowers the incidence of recurrent VTE as compared with placebo (relative risk [RR], 0.19, 95\% CI, 0.11-0.33), at a similar extent as the full-dose (RR, 0.20, 95\% CI, 0.11-0.34). ${ }^{69}$

Table 3 Therapeutic options for extended treatment

\begin{tabular}{|c|c|c|c|c|c|c|c|}
\hline & Apixaban & Edoxaban & Rivaroxaban & Dabigatran & VKA & ASA & Sulodexide \\
\hline Dosage & 2.5 or $5 \mathrm{mg}$ bid & $60 \mathrm{mg} \mathrm{od}^{\mathrm{a}}$ & 10 or $20 \mathrm{mg}$ od & $150 \mathrm{mg} \mathrm{bid}^{\mathrm{b}}$ & INR range: $2-3$ & $100 \mathrm{mg}$ od & $\begin{array}{l}500 \text { lipasemic } \\
\text { units bid }\end{array}$ \\
\hline
\end{tabular}

Abbreviations: ASA, acetylsalicylic acid; Cl, confidence interval; HR, hazard ratio; INR, international normalized ratio; RR, relative risk; VKA, vitamin K antagonists; VTE, venous thromboembolism.

${ }^{a}$ Doses should be reduced, as tested in the Hokusai trial and according the Summary of Product Characteristics, to $30 \mathrm{mg}$ od for patients with one or more of the following factors: creatinine clearance $15-50 \mathrm{~mL} / \mathrm{min}$; body weight $\leq 60 \mathrm{~kg}$; concomitant treatment with potent P-gp inhibitors (ciclosporin, dronedarone, erythromycin, ketoconazole).

bDoses should be reduced, according the Summary of Product Characteristics (not directly tested in the RE-MEDY and RE-SONATE trials), to 110 mg bid for patients aged $\geq 80$ years and/or receiving concomitant verapamil and should be considered for the following groups, based on an individual assessment of the thromboembolic risk and the risk of bleeding:

- Patients between 75 and 80 years.

- Patients with moderate renal impairment.

- Patients with gastritis, oesophagitis or gastro-oesophageal reflux.

- Other patients at increased risk of bleeding.

'As compared with ASA $100 \mathrm{mg}$. 
In the EINSTEIN-Extension trial, rivaroxaban was also found to significantly reduce the risk of recurrent VTE, as compared with placebo (HR, 0.18, 95\% CI, 0.09-0.39). ${ }^{9}$

Very recently, the EINSTEIN-Choice trial was published, comparing rivaroxaban $20 \mathrm{mg}$ and rivaroxaban $10 \mathrm{mg}$ to ASA $100 \mathrm{mg}^{70}$ The results demonstrated superiority of both doses of rivaroxaban as compared with ASA (HR, 0.34, 95\% CI, 0.20-0.59 and HR, 0.26, 95\% CI, 0.14-0.47, respectively), with a non-statistically different risk of major bleeding.

The rationale for including ASA in the EINSTEIN-Choice trial relies on the results of two studies (WARFASA and ASPIRE) 71,72 that demonstrated efficacy of low-dose ASA in reducing the risk of VTE recurrence (HR, $0.68,95 \% \mathrm{CI}, 0.51-0.90)$, as well as arterial thrombosis ( $\mathrm{HR}, 0.66,95 \% \mathrm{CI}, 0.51-0.86$ ), after an unprovoked VTE event, with a non-significant increased risk of major bleeding (HR, 1.47, 95\% CI, 0.70-3.08). ${ }^{73}$ Based on these results, evidence-based guidelines suggest aspirin over no aspirin to prevent recurrent VTE (Grade 2B), in patients with an unprovoked proximal DVT or PE who are stopping anticoagulant therapy and do not have a contraindication to aspirin. ${ }^{18}$ However, this recommendation is now questionable after the results of the EINSTEIN-Choice study.

Finally, sulodexide, a natural glycosaminoglycan with antithrombotic and profibrinolytic activities, was recently compared with placebo in patients with a first unprovoked VTE after completion of VKA therapy for 3 to 12 months (SURVET) ${ }^{74}$ Sulodexide was effective in reducing the risk of recurrent VTE by $51 \%$ without increasing the risk of bleeding.

\section{Future Perspectives}

The role of the DOACs in the treatment of PE in different risk sub-groups is currently explored in several on-going studies. The HoT-PE Trial (home treatment of patients with low-risk $\mathrm{PE}$ with the oral factor Xa inhibitor rivaroxaban) is a prospective cohort study enrolling low risk PE patients (defined by the absence of RVD by means of CT or echocardiography parameters) who receive rivaroxaban and are discharged within 48 hours from PE diagnosis (EudraCT Nr. 2013001657-28). ${ }^{75}$ The MERCURY PE (Multicenter Trial of Rivaroxaban for Early Discharge of Pulmonary Embolism From the Emergency Department) study is also assessing rivaroxaban in low-risk PE patients using the Hestia criteria. ${ }^{76}$

Dabigatran is currently tested in a trial enrolling patients at intermediate risk of adverse outcomes, defined by either imaging or laboratory evidence of RVD (Safety and Efficacy of Low Molecular Weight Heparin for 72 Hours Followed by Dabigatran for the Treatment of Acute Intermediate-Risk Pulmonary Embolism-PEITHO-2, ClinicalTrials.gov: NCT02596555). In this study, dabigatran is administered 72 hours after heparin initial treatment, instead of the 5 days used in the registration trials.

Moreover, besides PE, several trials are testing DOACs on additional VTE-related indications and/or in special populations (-Table 4).

Finally, a new compound, acting on the endogenous fibrinolytic system, has been recently tested in a phase I trial $^{77}$ and is currently used in a phase Ib trial on top of

Table 4 On-going trials on VTE-related indications for direct oral anticoagulants

\begin{tabular}{|c|c|c|c|c|}
\hline Study & Population & Intervention & Comparison & Primary Outcome \\
\hline $\begin{array}{l}\text { Venous Thromboembo- } \\
\text { lism in Renally Impaired } \\
\text { Patients and Direct Oral } \\
\text { Anticoagulants (VERDICT) } \\
\text { NCT02664155 }\end{array}$ & $\begin{array}{l}\text { Acute VTE patients with } \\
\text { moderate or severe } \\
\text { renal insufficiency }\end{array}$ & $\begin{array}{l}\text { Rivaroxaban ( } 15 \mathrm{mg} \text { od } \\
\text { after standard } 3 \mathrm{wk} \\
\text { loading dose), apixaban } \\
\text { ( } 2.5 \text { bid after standard } \\
1 \text { wk loading dose) }\end{array}$ & $\begin{array}{l}\text { LMWH/UFH } \\
\text { Warfarin }\end{array}$ & $\begin{array}{l}\text { Recurrent VTE and } \\
\text { major bleeding }\end{array}$ \\
\hline $\begin{array}{l}\text { Treatment of Splanchnic } \\
\text { Vein Thrombosis With } \\
\text { Rivaroxaban. A Pilot, } \\
\text { Prospective Cohort Study } \\
\text { (RivaSVT100) } \\
\text { NCT02627053 }\end{array}$ & $\begin{array}{l}\text { Acute portal, mesen- } \\
\text { teric or splenic vein } \\
\text { thrombosis }\end{array}$ & $\begin{array}{l}\text { Rivaroxaban (standard } \\
\text { dosing) }\end{array}$ & $\begin{array}{l}\text { Not } \\
\text { applicable }\end{array}$ & Major bleeding \\
\hline $\begin{array}{l}\text { Xarelto Versus no Treat- } \\
\text { ment for the Prevention of } \\
\text { Recurrent Thrombosis in } \\
\text { Patients With Chronic } \\
\text { Portal Vein Thrombosis } \\
\text { (RIPORT) NCT02555111 }\end{array}$ & $\begin{array}{l}\text { Chronic portal vein } \\
\text { thrombosis }\end{array}$ & Rivaroxaban $15 \mathrm{mg}$ od & $\begin{array}{l}\text { No } \\
\text { anticoagulation }\end{array}$ & $\begin{array}{l}\text { Thromboembolic } \\
\text { events (arterial or } \\
\text { venous) or death }\end{array}$ \\
\hline $\begin{array}{l}\text { Apixaban for the } \\
\text { Secondary Prevention of } \\
\text { Thromboembolism } \\
\text { Among Patients With the } \\
\text { AntiphosPholipid } \\
\text { Syndrome (ASTRO-APS) } \\
\text { NCT02295475 }\end{array}$ & $\begin{array}{l}\text { Antiphospholipid } \\
\text { syndrome }\end{array}$ & Apixaban $5 \mathrm{mg}$ bid & $\begin{array}{l}\text { Warfarin } \\
\text { (INR, 2-3) }\end{array}$ & $\begin{array}{l}\text { Arterial and/or venous } \\
\text { thrombosis }\end{array}$ \\
\hline $\begin{array}{l}\text { Rivaroxaban in Thrombotic } \\
\text { Antiphospholipid } \\
\text { Syndrome (TRAPS) } \\
\text { NCT02157272 }\end{array}$ & $\begin{array}{l}\text { Triple-positive antipho- } \\
\text { spholipid syndrome }\end{array}$ & $\begin{array}{l}\text { Rivaroxaban } 20 \mathrm{mg} \text { od } \\
\text { (15 mg if creatinine } \\
\text { clearance between } \\
30 \text { and } 49 \mathrm{~mL} / \mathrm{min} \text { ) }\end{array}$ & $\begin{array}{l}\text { Warfarin } \\
\text { (INR, 2-3) }\end{array}$ & $\begin{array}{l}\text { Arterial and/or venous } \\
\text { thrombosis, } \\
\text { major bleeding or death }\end{array}$ \\
\hline
\end{tabular}

(Continued) 
Table 4 (Continued)

\begin{tabular}{|c|c|c|c|c|}
\hline Study & Population & Intervention & Comparison & Primary Outcome \\
\hline $\begin{array}{l}\text { Apixaban for the Acute } \\
\text { Treatment of Venous } \\
\text { Thromboembolism in } \\
\text { Children NCT02464969 }\end{array}$ & Acute VTE & $\begin{array}{l}\text { Apixaban }(10 \mathrm{mg} \text { bid } \\
\text { for } 7 \mathrm{~d} \text {, then } 5 \mathrm{mg} \text { bid } \\
\text { for weight } \geq 35 \mathrm{~kg} ; \\
0.28 \mathrm{mg} / \mathrm{kg} \text { bid for } 7 \mathrm{~d} \\
\text { then } 0.14 \mathrm{mg} / \mathrm{kg} \text { twice } \\
\text { daily for weight } \\
<35 \mathrm{~kg} \text { ) }\end{array}$ & $\begin{array}{l}\text { Standard } \\
\text { of care }\end{array}$ & $\begin{array}{l}\text { Major and clinically } \\
\text { relevant non-major } \\
\text { bleeding }\end{array}$ \\
\hline $\begin{array}{l}\text { Oral Rivaroxaban in } \\
\text { Children With Venous } \\
\text { Thrombosis (EINSTEIN Jr) } \\
\text { NCT02234843 }\end{array}$ & Acute VTE & $\begin{array}{l}\text { Rivaroxaban (age and } \\
\text { body weight-adjusted } \\
\text { dosing equivalent to } \\
20 \mathrm{mg} \text { in adults, once } \\
\text { daily, twice or three } \\
\text { times daily) }\end{array}$ & $\begin{array}{l}\text { Standard } \\
\text { of care }\end{array}$ & Recurrent VTE \\
\hline $\begin{array}{l}\text { Open Label Study } \\
\text { Comparing Efficacy and } \\
\text { Safety of Dabigatran } \\
\text { Etexilate to Standard of } \\
\text { Care in Pediatric Patients } \\
\text { With Venous } \\
\text { Thromboembolism } \\
\text { NCT01895777 }\end{array}$ & $\begin{array}{l}\text { Acute VTE, initially } \\
\text { treated with parenteral } \\
\text { anticoagulation } \\
\text { therapy }\end{array}$ & $\begin{array}{l}\text { Dabigatran (age and } \\
\text { weight appropriate } \\
\text { dose) }\end{array}$ & $\begin{array}{l}\text { Standard } \\
\text { of care }\end{array}$ & $\begin{array}{l}\text { Co-primary: } \\
\text {-Complete thrombus } \\
\text { resolution, recurrent } \\
\text { VTE, VTE related } \\
\text { mortality } \\
\text {-Major bleeding }\end{array}$ \\
\hline $\begin{array}{l}\text { A Clinical Trial Comparing } \\
\text { Efficacy and Safety of } \\
\text { Dabigatran Etexilate With } \\
\text { Warfarin in Patients With } \\
\text { Cerebral Venous and Dural } \\
\text { Sinus Thrombosis } \\
\text { (RE-SPECT CVT) } \\
\text { NCT02913326 }\end{array}$ & $\begin{array}{l}\text { Cerebral venous or } \\
\text { dural sinus thrombosis } \\
\text { initially treated with } \\
\text { parenteral anticoagula- } \\
\text { tion therapy }\end{array}$ & $\begin{array}{l}\text { Dabigatran } \\
\text { (standard dosing) }\end{array}$ & Warfarin & $\begin{array}{l}\text { Major bleeding and VTE } \\
\text { events }\end{array}$ \\
\hline
\end{tabular}

Abbreviations: INR, international normalized ratio; LMWH, low-molecular weight heparin; UFH, unfractionated heparin; VTE, venous thromboembolism.

standard therapy for haemodynamically stable PE patients. This drug (DS1040) acts as an inhibitor of the activated form of thrombin-activatable fibrinolysis inhibitor (TAFIa), thus enhancing the endogenous fibrinolysis.

\section{Conflict of Interest}

M.D. has no conflict of interest to declare. W.A. received research grant from Bayer and is in the advisory boards of Bayer, Boehringer Ingelheim, Daiichi Sankyo, Portola and Sanofi.

\section{References}

1 Konstantinides SV, Torbicki A, Agnelli G, et al; Task Force for the Diagnosis and Management of Acute Pulmonary Embolism of the European Society of Cardiology (ESC). 2014 ESC guidelines on the diagnosis and management of acute pulmonary embolism. Eur Heart J 2014;35(43):3033-3069, 3069a-3069k

2 Jaff MR, McMurtry MS, Archer SL, et al; American Heart Association Council on Cardiopulmonary, Critical Care, Perioperative and Resuscitation. American Heart Association Council on Peripheral Vascular Disease; American Heart Association Council on Arteriosclerosis, Thrombosis and Vascular Biology. Management of massive and submassive pulmonary embolism, iliofemoral deep vein thrombosis, and chronic thromboembolic pulmonary hypertension: a scientific statement from the American Heart Association. Circulation 2011; 123:788-830
3 Aujesky D, Obrosky DS, Stone RA, et al. Derivation and validation of a prognostic model for pulmonary embolism. Am J Respir Crit Care Med 2005;172(08):1041-1046

4 Jiménez D, Aujesky D, Moores L, et al; RIETE Investigators. Simplification of the pulmonary embolism severity index for prognostication in patients with acute symptomatic pulmonary embolism. Arch Intern Med 2010;170(15):1383-1389

5 Squizzato A, Donadini MP, Galli L, Dentali F, Aujesky D, Ageno W. Prognostic clinical prediction rules to identify a low-risk pulmonary embolism: a systematic review and meta-analysis. J Thromb Haemost 2012;10(07):1276-1290

6 McGinn TG, Guyatt GH, Wyer PC, Naylor CD, Stiell IG, Richardson WS; Evidence-Based Medicine Working Group. Users' guides to the medical literature: XXII: how to use articles about clinical decision rules. JAMA 2000;284(01):79-84

7 Schulman S, Kearon C, Kakkar AK, et al; RE-COVER Study Group. Dabigatran versus warfarin in the treatment of acute venous thromboembolism. N Engl J Med 2009;361(24):2342-2352

8 Schulman S, Kakkar AK, Goldhaber SZ, et al; RE-COVER II Trial Investigators. Treatment of acute venous thromboembolism with dabigatran or warfarin and pooled analysis. Circulation 2014;129 (07):764-772

9 Bauersachs R, Berkowitz SD, Brenner B, et al; EINSTEIN Investigators. Oral rivaroxaban for symptomatic venous thromboembolism. N Engl J Med 2010;363(26):2499-2510

10 Büller HR, Prins MH, Lensin AW, et al; EINSTEIN-PE Investigators. Oral rivaroxaban for the treatment of symptomatic pulmonary embolism. N Engl J Med 2012;366(14):1287-1297 
11 Agnelli G, Buller HR, Cohen A, et al; AMPLIFY Investigators. Oral apixaban for the treatment of acute venous thromboembolism. N Engl J Med 2013;369(09):799-808

12 Büller HR, Décousus H, Grosso MA, et al; Hokusai-VTE Investigators. Edoxaban versus warfarin for the treatment of symptomatic venous thromboembolism. N Engl J Med 2013;369(15):1406-1415

13 van Es N, Coppens M, Schulman S, Middeldorp S, Büller HR. Direct oral anticoagulants compared with vitamin $\mathrm{K}$ antagonists for acute venous thromboembolism: evidence from phase 3 trials. Blood 2014;124(12):1968-1975

14 Ageno W, Mantovani LG, Haas S, et al. Safety and effectiveness of oral rivaroxaban versus standard anticoagulation for the treatment of symptomatic deep-vein thrombosis (XALIA): an international, prospective, non-interventional study. Lancet Haematol 2016;3(01):e12-e21

15 Kucher N, Aujesky D, Beer JH, et al. Rivaroxaban for the treatment of venous thromboembolism. The SWIss Venous ThromboEmbolism Registry (SWIVTER). Thromb Haemost 2016;116(03):472-479

16 Sindet-Pedersen C, Langtved Pallisgaard J, Staerk L, et al. Comparative safety and effectiveness of rivaroxaban versus VKAs in patients with venous thromboembolism. A Danish nationwide registrybased study. Thromb Haemost 2017;117(06):1182-1191

17 Larsen TB, Skjøth F, Kjældgaard JN, Lip GYH, Nielsen PB, Søgaard $M$. Effectiveness and safety of rivaroxaban and warfarin in patients with unprovoked venous thromboembolism: a propensity-matched nationwide cohort study. Lancet Haematol 2017;4 (05):e237-e244

18 Kearon C, Akl EA, Ornelas J, et al. Antithrombotic therapy for VTE disease: CHEST Guideline and Expert Panel Report. Chest 2016; 149(02):315-352

19 Heidbuchel H, Verhamme P, Alings M, et al. Updated European Heart Rhythm Association Practical Guide on the use of nonvitamin $\mathrm{K}$ antagonist anticoagulants in patients with non-valvular atrial fibrillation. Europace 2015;17(10):1467-1507

20 Hutten BA, Prins MH, Gent M, Ginsberg J, Tijssen JG, Büller HR. Incidence of recurrent thromboembolic and bleeding complications among patients with venous thromboembolism in relation to both malignancy and achieved international normalized ratio: a retrospective analysis. J Clin Oncol 2000;18(17):3078-3083

21 Prandoni P, Lensing AW, Piccioli A, et al. Recurrent venous thromboembolism and bleeding complications during anticoagulant treatment in patients with cancer and venous thrombosis. Blood 2002;100(10):3484-3488

22 Farge D, Debourdeau P, Beckers M, et al. International clinical practice guidelines for the treatment and prophylaxis of venous thromboembolism in patients with cancer. J Thromb Haemost 2013;11(01):56-70

23 Lyman GH, Bohlke K, Khorana AA, et al; American Society of Clinical Oncology. Venous thromboembolism prophylaxis and treatment in patients with cancer: American Society of Clinical Oncology Clinical Practice Guideline update 2014. J Clin Oncol 2015;33(06):654-656

24 Mandalà M, Falanga A, Roila F; ESMO Guidelines Working Group. Management of venous thromboembolism (VTE) in cancer patients: ESMO Clinical Practice Guidelines. Ann Oncol 2011;22 (Suppl 6):vi85-vi92

25 Akl EA, Kahale L, Barba M, et al. Anticoagulation for the long-term treatment of venous thromboembolism in patients with cancer. Cochrane Database Syst Rev 2014;7(07):CD006650

26 Vedovati MC, Germini F, Agnelli G, Becattini C. Direct oral anticoagulants in patients with VTE and cancer: a systematic review and meta-analysis. Chest 2015;147(02):475-483

27 van Es N, Di Nisio M, Bleker SM, et al. Edoxaban for treatment of venous thromboembolism in patients with cancer. Rationale and design of the Hokusai VTE-cancer study. Thromb Haemost 2015; 114(06):1268-1276

28 Aujesky D, Roy PM, Verschuren F, et al. Outpatient versus inpatient treatment for patients with acute pulmonary embolism: an international, open-label, randomised, non-inferiority trial. Lancet 2011;378(9785):41-48

29 Zondag W, Mos IC, Creemers-Schild D, et al; Hestia Study Investigators. Outpatient treatment in patients with acute pulmonary embolism: the Hestia Study. J Thromb Haemost 2011;9(08):1500-1507

30 den Exter PL, Zondag W, Klok FA, et al; Vesta Study Investigators. Efficacy and safety of outpatient treatment based on the Hestia Clinical Decision Rule with or without N-terminal pro-brain natriuretic peptide testing in patients with acute pulmonary embolism. A randomized clinical trial. Am J Respir Crit Care Med 2016;194(08):998-1006

31 Stein PD, Matta F, Hughes PG, et al. Home treatment of pulmonary embolism in the era of novel oral anticoagulants. Am J Med 2016; 129(09):974-977

32 Jiménez D, de Miguel-Díez J, Guijarro R, et al. RIETE Investigators. Trends in the management and outcomes of acute pulmonary embolism: analysis from the RIETE Registry. J Am Coll Cardiol 2016;67(02):162-170

33 Donadini MP, Dentali F, Castellaneta M, et al; LORPELHS Study Group. Pulmonary embolism prognostic factors and length of hospital stay: a cohort study. Thromb Res 2017;156:155-159

34 Meyer G, Vicaut E, Danays T, et al; PEITHO Investigators. Fibrinolysis for patients with intermediate-risk pulmonary embolism. N Engl J Med 2014;370(15):1402-1411

35 Brekelmans MP, Ageno W, Beenen LF, et al. Recurrent venous thromboembolism in patients with pulmonary embolism and right ventricular dysfunction: a post-hoc analysis of the HokusaiVTE study. Lancet Haematol 2016;3(09):e437-e445

36 Boutitie F, Pinede L, Schulman S, et al. Influence of preceding length of anticoagulant treatment and initial presentation of venous thromboembolism on risk of recurrence after stopping treatment: analysis of individual participants' data from seven trials. BMJ 2011;342:d3036

37 Couturaud F, Sanchez O, Pernod G, et al; PADIS-PE Investigators. Six months vs extended oral anticoagulation after a first episode of pulmonary embolism: the PADIS-PE Randomized Clinical Trial. JAMA 2015;314(01):31-40

38 Ageno W, Samperiz A, Caballero R, et al; RIETE Investigators. Duration of anticoagulation after venous thromboembolism in real world clinical practice. Thromb Res 2015;135(04):666-672

39 Baglin T, Luddington R, Brown K, Baglin C. Incidence of recurrent venous thromboembolism in relation to clinical and thrombophilic risk factors: prospective cohort study. Lancet 2003;362(9383):523-526

40 Iorio A, Kearon C, Filippucci E, et al. Risk of recurrence after a first episode of symptomatic venous thromboembolism provoked by a transient risk factor: a systematic review. Arch Intern Med 2010; 170(19):1710-1716

41 Kearon C, Ageno W, Cannegieter SC, Cosmi B, Geersing GJ, Kyrle PA; Subcommittees on Control of Anticoagulation, and Predictive and Diagnostic Variables in Thrombotic Disease. Categorization of patients as having provoked or unprovoked venous thromboembolism: guidance from the SSC of ISTH. J Thromb Haemost 2016; 14(07):1480-1483

42 Prandoni P, Lensing AW, Prins MH, et al. Residual venous thrombosis as a predictive factor of recurrent venous thromboembolism. Ann Intern Med 2002;137(12):955-960

43 Prandoni P, Prins MH, Lensing AW, et al. AESOPUS Investigators. Residual thrombosis on ultrasonography to guide the duration of anticoagulation in patients with deep venous thrombosis: a randomized trial. Ann Intern Med 2009;150(09):577-585

44 Cosmi B, Legnani C, Cini M, Guazzaloca G, Palareti G. D-dimer levels in combination with residual venous obstruction and the risk of recurrence after anticoagulation withdrawal for a first idiopathic deep vein thrombosis. Thromb Haemost 2005;94(05):969-974

45 Young L, Ockelford P, Milne D, Rolfe-Vyson V, Mckelvie S, Harper P. Post-treatment residual thrombus increases the risk of recurrent deep vein thrombosis and mortality. J Thromb Haemost 2006;4 (09):1919-1924 
46 Siragusa S, Malato A, Anastasio R, et al. Residual vein thrombosis to establish duration of anticoagulation after a first episode of deep vein thrombosis: the duration of anticoagulation based on Compression UltraSonography (DACUS) study. Blood 2008;112 (03):511-515

47 LE Gal G, Carrier M, Kovacs MJ, et al. Residual vein obstruction as a predictor for recurrent thromboembolic events after a first unprovoked episode: data from the REVERSE cohort study. J Thromb Haemost 2011;9(06):1126-1132

48 Donadini MP, Ageno W, Antonucci E, et al. Prognostic significance of residual venous obstruction in patients with treated unprovoked deep vein thrombosis: a patient-level meta-analysis. Thromb Haemost 2014;111(01):172-179

49 Pesavento R, Filippi L, Palla A, et al. SCOPE Investigators. Impact of residual pulmonary obstruction on the long-term outcome of patients with pulmonary embolism. Eur Respir J 2017;49 pii: 1601980. Doi: 10.1183/13993003.01980-2016

50 Planquette B, Ferré A, Peron J, et al. Residual pulmonary vascular obstruction and recurrence after acute pulmonary embolism. A single center cohort study. Thromb Res 2016;148:70-75

51 Palareti G, Cosmi B, Legnani C, et al; PROLONG Investigators. Ddimer testing to determine the duration of anticoagulation therapy. N Engl J Med 2006;355(17):1780-1789

52 Cosmi B, Legnani C, Tosetto A, et al; PROLONG Investigators (on behalf of Italian Federation of Anticoagulation Clinics). Usefulness of repeated D-dimer testing after stopping anticoagulation for a first episode of unprovoked venous thromboembolism: the PROLONG II prospective study. Blood 2010;115(03):481-488

53 Palareti G, Cosmi B, Legnani C, et al; DULCIS (D-dimer and ULtrasonography in Combination Italian Study) Investigators. D-dimer to guide the duration of anticoagulation in patients with venous thromboembolism: a management study. Blood 2014;124(02):196-203

54 Ensor J, Riley RD, Moore D, Snell KI, Bayliss S, Fitzmaurice D. Systematic review of prognostic models for recurrent venous thromboembolism (VTE) post-treatment of first unprovoked VTE. BMJ Open 2016;6(05):e011190

55 Rodger MA, Kahn SR, Wells PS, et al. Identifying unprovoked thromboembolism patients at low risk for recurrence who can discontinue anticoagulant therapy. CMAJ 2008;179(05):417-426

56 Rodger MA, Le Gal G, Anderson DR, et al; REVERSE II Study Investigators. Validating the HERDOO2 rule to guide treatment duration for women with unprovoked venous thrombosis: multinational prospective cohort management study. BMJ 2017;356 j1065. Doi: 10.1136/bmj.j1065

57 Tosetto A, Iorio A, Marcucci M, et al. Predicting disease recurrence in patients with previous unprovoked venous thromboembolism: a proposed prediction score (DASH). J Thromb Haemost 2012;10 (06):1019-1025

58 Tosetto A, Testa S, Martinelli I, et al. External validation of the DASH prediction rule: a retrospective cohort study. J Thromb Haemost 2017;15(10):1963-1970

59 Eichinger S, Heinze G, Jandeck LM, Kyrle PA. Risk assessment of recurrence in patients with unprovoked deep vein thrombosis or pulmonary embolism: the Vienna prediction model. Circulation 2010;121(14):1630-1636

60 Eichinger S, Heinze G, Kyrle PA. D-dimer levels over time and the risk of recurrent venous thromboembolism: an update of the Vienna prediction model. J Am Heart Assoc 2014;3(01):e000467

61 Cost-effectiveness of tailoring anticoagulant therapy by a VTE recurrence prediction model in patients with venous thromboembolism as compared to care-as-usual: the VISTA study. Available at: http://www.trialregister.nl/trialreg/admin/rctview. asp?TC=2680. Accessed July 6, 2017
62 Riva N, Bellesini M, Di Minno MN, et al. Poor predictive value of contemporary bleeding risk scores during long-term treatment of venous thromboembolism. A multicentre retrospective cohort study. Thromb Haemost 2014;112(03):511-521

63 Nieto JA, Solano R, Trapero Iglesias N, et al; RIETE Investigators. Validation of a score for predicting fatal bleeding in patients receiving anticoagulation for venous thromboembolism. Thromb Res 2013;132(02):175-179

64 Klok FA, Barco S, Konstantinides SV. External validation of the VTE-BLEED score for predicting major bleeding in stable anticoagulated patients with venous thromboembolism. Thromb Haemost 2017;117(06):1164-1170

65 Palareti G, Leali N, Coccheri S, et al; Italian Study on Complications of Oral Anticoagulant Therapy. Bleeding complications of oral anticoagulant treatment: an inception-cohort, prospective collaborative study (ISCOAT). Lancet 1996;348(9025):423-428

66 Ridker PM, Goldhaber SZ, Danielson E, et al; PREVENT Investigators. Long-term, low-intensity warfarin therapy for the prevention of recurrent venous thromboembolism. N Engl J Med 2003; 348(15):1425-1434

67 Kearon C, Ginsberg JS, Kovacs MJ, et al; Extended Low-Intensity Anticoagulation for Thrombo-Embolism Investigators. Comparison of low-intensity warfarin therapy with conventional-intensity warfarin therapy for long-term prevention of recurrent venous thromboembolism. N Engl J Med 2003;349(07):631-639

68 Schulman S, Kearon C, Kakkar AK, et al; RE-MEDY Trial Investigators; RE-SONATE Trial Investigators. Extended use of dabigatran, warfarin, or placebo in venous thromboembolism. N Engl J Med 2013;368(08):709-718

69 Agnelli G, Buller HR, Cohen A, et al; AMPLIFY-EXT Investigators. Apixaban for extended treatment of venous thromboembolism. N Engl J Med 2013;368(08):699-708

70 Weitz JI, Lensing AWA, Prins MH, et al; EINSTEIN CHOICE Investigators. Rivaroxaban or aspirin for extended treatment of venous thromboembolism. N Engl J Med 2017;376(13):1211-1222

71 Becattini C, Agnelli G, Schenone A, et al; WARFASA Investigators. Aspirin for preventing the recurrence of venous thromboembolism. N Engl J Med 2012;366(21):1959-1967

72 Brighton TA, Eikelboom JW, Mann K, et al; ASPIRE Investigators. Low-dose aspirin for preventing recurrent venous thromboembolism. N Engl J Med 2012;367(21):1979-1987

73 Simes J, Becattini C, Agnelli G, et al; INSPIRE Study Investigators (International Collaboration of Aspirin Trials for Recurrent Venous Thromboembolism). Aspirin for the prevention of recurrent venous thromboembolism: the INSPIRE collaboration. Circulation 2014;130(13):1062-1071

74 Andreozzi GM, Bignamini AA, Davì G, et al; SURVET Study Investigators. Sulodexide for the prevention of recurrent venous thromboembolism: the Sulodexide in Secondary Prevention of Recurrent Deep Vein Thrombosis (SURVET) Study: a multicenter, randomized, double-blind, placebo-controlled trial. Circulation 2015;132(20):1891-1897

75 Barco S, Lankeit M, Binder $\mathrm{H}$, et al. Home treatment of patients with low-risk pulmonary embolism with the oral factor Xa inhibitor rivaroxaban. Rationale and design of the HoT-PE Trial. Thromb Haemost 2016;116(01):191-197

76 Singer AJ, Xiang J, Kabrhel C, et al. Multicenter Trial of Rivaroxaban for Early Discharge of Pulmonary Embolism From the Emergency Department (MERCURY PE): rationale and design. Acad Emerg Med 2016;23(11):1280-1286

77 Zhou J, Kochan J, Yin O, et al. A first-in-human study of DS-1040, an inhibitor of the activated form of thrombin-activatable fibrinolysis inhibitor, in healthy subjects. J Thromb Haemost 2017;15 (05):961-971 